\title{
VARIAN PEMIKIRAN DAN GERAKAN KEAGAMAAN MAHASISWA DI BERBAGAI UNIVERSITAS
}

\author{
Variants Thoughts and Religious Movements Students in Various Universities \\ Sulaiman * \\ *Balai Litbang Agama Semarang \\ Email : sulaiman.litbang@yahoo.com
}

Koreksi naskah I tanggal 17 Juni 2012. Koreksi naskah II tanggal 10 Juli 2012. Finalisasi Naskah 9 Oktober 2012

\begin{abstract}
Abstrak
Penelitian ini bertujuan untukmengetahui varian pemikiran dan gerakan keagamaan mahasiswa di berbagai universitas. Dalam hal ini, fokus kajian berada di tiga universitas, yakni UGM Yogjakarta, Universitas Airlangga Surabaya, dan UNS Surakarta. Dalam penelitian ini, pendekatan yang digunakan adalah mixed methods, yakni suatu pendekatan yang merupakan kombinasi kuantitatif dan kualitatif Pendekatan ini dimaksudkan untuk memperkuat kesahihan temuan-temuan penelitian, sehingga teknik pengumpulan data kuantitatif menggunakan questioner dan hasil temuannya ditindaklanjuti dengan pengumpulan data observasi, wawancara dan FGD (focus group discussion). Hasil penelitian ini menunjukkan bahwa pemikiran keagamaan memiliki pengaruh yang signifikan terhadap gerakan keagamaan mahasiswa, meskipun temuannya tidak sinergis antara kedua variabel itu. Pemikiran keagamaan cenderung cukup kontekstual, namun gerakan keagamaan cenderung radikal. Hal ini mungkin terjadi karena orientasi pemikiran keagamaan mahasiswa bukan kepada ideologi gerakannya, melainkan kegiatan keislamannya.
\end{abstract}

Kata Kunci: Pemikiran keagamaan, motivasi, komunikasi, gerakan keagamaan

\begin{abstract}
This study aims to determine the variants of religious thought and movement students at various universities. In this case, the focus of study is in three universities, namely UGM Yogyakarta, Airlangga University, and UNS Surakarta. In this study, the approach used is mixed methods, ie, an approach that is a combination of quantitative and qualitative. This approach is intended to strengthen the validity of the findings of the study, so the quantitative data collection technique using a questionnaire and followed up findings with data collection observation, interviews and FGDs (focus group discussion). The results of this study indicate that religious thought has a significant effect on student religious movement, although findings are not synergy between the two variables. Religious thought tends to be quite contextual, but religious movements tend to be radical. This may occur because the orientation of students of religious thought not to ideological movements, but their Islamic activities.
\end{abstract}

Keywords: religious thinking, motivation, communication, religious movements

\section{PENDAHULUAN}

Berubahnya sistem politik pasca runtuhnya Orde Baru, membawa pengaruh bagi perkembangan Islam dan ormas Islam. Berbagai kelompok muncul, baik dari sayap radikal yang berorientasi pada perubahan sistem sosial dan politik (radikal)' maupun sayap liberal yang berorientasi sebaliknya. Berdiri di tengahnya adalah sayap Islam moderat yang harus menerima tekanan dari berbagai sisi tersebut. ${ }^{2}$ Ketiga sayap Islam ini saling berebut klaim dan pengaruh, tidak jarang menimbulkan benturan terbuka di masyarakat. Islam radikal atau Islam garis keras termasuk yang paling banyak menikmati keterbukaan sistem politik ini.

Salah satu gerakan Islam yang berkembang pesat adalah paham salaf yakni memahami dan melaksanakan ajaran agama Islam secara harfiyyah sesuai

\footnotetext{
Radikalisme keagamaan adalah gerakan keagamaan yang berusaha merombak secara total suatu tatanan politik atau sosial yang ada dengan menggunakan kekerasan. Baca Sartono Kartodirdjo, Ratu Adil, (Jakarta: Sinar Harapan, 1985), h. 38.

'Indonesia:Pasar Bebas Ideologi Islam, dalam Jurnal Tashwirul Afkar, Edisi No. 21 Tahun 2007, h. $20-21$.
} 
yang termaktub dalam Alquran dan sunnah shahihah. Pemahaman keagamaan tersebut dikembangkan oleh kelompok Salafi, Hizbut Tahrir, Majelis Mujahidin Indonesia dan yang lainnya.

Berkaitan dengan kehadiran pemikiran keagamaan kontemporer, Imam Tholkhah dan Abdul Aziz mengemukakan bahwa gerakan Islam kontemporer setidaknya bersumber dari empat faktor laten: Pertama, pandangan pemurnian agama yang tidak hanya terbatas kepada praktik keagamaan, melainkan juga pemurnian atas sumber agama itu sendiri yaitu penolakan terhadap sumber ajaran selain Alquran. Kedua dorongan untuk mendobrak kemapanan paham keagamaan mainstream yang berkaitan dengan kebebasan setiap Muslim untuk menjadi pemimpin bagi dirinya dalam memahami ajaran Islam dan tidak terikat (taklid buta) dalam bentuk apapun. Ketiga pandangan tentang sistem kemasyarakatan yang diidealisasikan seperti kepemimpinan tunggal dibawah seorang amir, atau sistem umah wahidah (khilafah Islamiyyah). Keempat sikap (menolak) terhadap pengaruh Barat seperti modernisme, sekularisme, kapitalismedan lainnya.Dalam konteks ini Islam ditempatkan sebagai sistem alternatif yang mengungguli paham atau ideologi tersebut.

Perkembangan pemahaman keagamaan tersebut terus berjalan dan sampai merambah ke dunia kampus terutama kalangan mahasiswa di berbagai Universitas. Sistem kehidupan kampus modern lebih merupakan sistem kehidupan terbuka.Akibatnya, mereka yang mulai menjalani kehidupan sebagai mahasiswa modern mengalami keterkejutan keagamaan.Ketika mahasiswa memerlukan bimbingan dalam situasi baru, justru dakwah dan khutbah-khutbah pemikiran Islam fundamental dan radikal lebih mempertajam keterkejutan keagamaan tanpa alternatif yang lebih berarti.Karena itu, mereka sangat intensif melakukan kajian-kajian Islam yang cenderung memperkuat budaya keagamaannya.Akibatnya, mahasiswa kampus modern mudah dimobilisasi dalam kajian intensif maupun kegiatan ekslusif. ${ }^{4}$

Fenomena pemikiran dan gerakan keagamaan di berbagai kampus di Indonesia merupakan suatu realita yang patut dikaji lebih dalam.Fenomena ini makin terlihat di beberapa universitas umum dan atau perguruan tinggi umum (PTU) yang tidak berafiliasi
keagamaan.Para mahasiswa di beberapa universitas tersebut memiliki aktivitas keagamaan yang ditengarai memiliki pemikiran yang mengarah kepada paham tekstualis atau fundamentalis.PemMrm keagamaan yang bersifat fundamentalis adalah pemahaman keagamaan yang bersifat normatif dan harfiyyah dalam memahami ajaran pokok agama.Fenomena tersebut dapat diamati secara sepintas dalam berbagai aktivitas keagamaan yang berkembang di berbagai kampus di tanah air, biasanya terdapat kelompok kajian keagamaan yang menekankan terhadap kajian teks secara literal.

Berangkat dari latar belakang tersebut, kiranya penting untuk dilakukan penelitian mengenai varian pemikiran keagamaan dan gerakan keagamaan mahasiswa di berbagai universitas negeri non afiliasi Kementerian Agama. Oleh karena itu, masalah penelitian adalah "bagaimanakah varian-varian pemikiran dan gerakan keagamaan mahasiswa, dan sejauhmana pengaruh pemikiran keagamaan terhadap gerakan keagamaan mahasiswa diUGM Yogjakarta, Universitas Airlangga Surabaya, dan UNS Surakarta".

Penelitian ini diharapkan mampu menghasilkan gambaran tentang peta pemikiran keagamaan mahasiswa dan signifikansi pengaruh pemikiran keagamaan terhadap gerakan keagamaan mahasiswa di berbagai universitas umum non Kementerian Agama. Karena itu, hasil penelitian ini dapat menjadi bahan evaluasi bagi pengembangan dan pembinaan keagamaan di kalangan Perguruan Tinggi Umum.

Penelitian ini menggunakan pendekatan mixed methods, yakni suatu penelitian yang menerapkan kombinasi dua pendekatan (kualitatif dan kuantitatif) dalam satu penelitian. Penelitian ini dimaksudkan untuk memperoleh pemahaman yang lebih baik dan sekaligus memperluas pembahasan. Selain itu, pendekatan mixed methods dimaksudkan untuk memperkuat kesahihan temuan-temuan penelitian. Temuan dari satu jenis studi dapat dicek pada temuan-temuan yang diperoleh dari jenis studi yang lain.

Dalam penelitian kuantitatif, penelitian ini bersifat survey yang bersifat menjelaskan fenomena (explana-

\footnotetext{
3 Abdul Aziz dan Imam Tholkhah, ed., 1989.Gerakan Islam Kontemporer di Indonesia, Jakarta: PT. Temprint, h. 7

${ }^{4}$ Fatihul Himami, lOW.Islam Karbitan=Islam Radikal di Indonesia, http://www. diunduh tanggal 13 Maret 2012.

${ }^{5}$ Creswell, John W., 2Q Q.Research Desain: Pendekatan Kualitatif, Kuantitatif, Mixed, Yogakarta: Pustaka Pelajar, h. 304-311.

${ }^{6}$ Bramen, Yulia, 2002Memadu Metode Penelitian Kualitatif dan Kuantitatif, Yogjakarta: Pustaka Pelajar, h. 81.
} 
tory research).Tujuannya adalah untuk menjelaskan suatu keadaan yang terjadi ketika penelitian dilakukan dandirancang untuk menentukan besaran hubungan suatu variabel dengan variabel lain. ${ }^{\top}$ Variabel yang hendak dijelaskan dalam penelitian ini adalah gerakan keagamaan, sedangkan variabel yang menjelaskan yaitu pemikiran keagamaan, jaringan komunikasi dan motivasi keagamaan mahasiswa.Dalam pendekatan kualitatif, penelitian bersifat studi kasus yang mendeskripsikan variasi-variasi pemikiran keagamaan dan gerakan keagamaan mahasiswa ditiga universitas sasaran.

Dalam penelitian ini, sasaran penelitian adalah universitas negeri non agama yang berada di Jawa Tengah, Yogjakarta, dan Jawa Timur.Dalam hal ini, penelitian berada di UNS Surakarta, UGM Yogjakarta, dan Universitas Airlangga Surabaya.Alasan pemilihan lokasi didasarkan atas dinamika keberagamaan di tiga universitas tersebut.Atas pertimbangan ini, maka ketiga universitas tersebut dipandang cukup signifikan tingkat kemajuan aktivitas keagamaannya sebagai sasaran penelitan. Karena itu, populasi penelitian ini adalah mahasiswa muslim di tiga universitas dengan jumlah sampel responden sebanyak 495 mahasiswa. Dalam pemilihan sampel responden ini dilakukan secara proporsional sesuai dengan variasi organisasi mahasiswa intra, seperti UKMI, UKM Rohis, UKMKI dan atau SKI.

Dalam penelitian ini terdapat empat variabel, yakni gerakan keagamaan, pemikiran keagamaan, jaringan komunikasi dan motivasi keagamaan. Pengukuran atas keempat variabel tersebut dilakukan dengan menerapkan skala Likert dengan rentang skor 1 4.Penetapan rentang skor seperti ini dimaksudkan untuk menghindari kecenderungan responden untuk memilih skor tengah. Misalnya, apabila dalam suatu instrumen penelitian menggunakan rentang skor 5, ada kecenderungan responden akan memilih skor 3 . Dengan menetapkan rentang skor tersebut, responden yang memilih alternatif jawaban seperti yang diharapkan oleh peneliti akan diberikan skor tinggi, dan responden yang memilih alternatif jawaban yang tidak diharapkan oleh peneliti akan diberikan skor rendah.

Pengumpulan data dilakukan dengan menggunakan angket, wawancara mendalam dan FGD. Angket digunakan untuk mengumpulkan data tentang pemikiran keagamaan, gerakan keagamaan, jaringan komunikasi dan motivasi keagamaan. Wawancara digunakan untuk mendalami data dan informasi yang diperoleh melalui angket. Sedangkan FGD digunakan untuk mengungkap persoalan yang sebenarnya berkenaan dengan varian pemikiran dan gerakan keagamaan mahasiswa. Hal ini sesuai dengan maksud dan tujuan FGD (focus group discussion), yakni menemukan makna sebuah tema menurut pemahaman sebuah kelompok sehingga terhindar dari pemaknaan yang salah dari seorang peneliti terhadap fokus masalah yang sedang diteliti.

Analisis data dalam penelitian ini meliputi dua tahap, yakni analisis deskriptif dan analisis korelasional. Data yang telah dikumpulkan dan ditabulasi, kemudian dianalisis secara deskriptif persentase dan penghitungan mean. Melalui penerapan analisis deskriptif persentase dan mean itu akan diperoleh gambaran secara utuh terhadap variabel-variabel penelitian. Untuk mengetahui kecenderungan data, selanjutnya ditetapkan standar kualifikasi berdasarkan hasil penghitungan mean dan standar deviasi. Hasil perolehan mean dan standar deviasi itu kemudian dijadikan sebagai landasan untuk menetapkan kualifikasi, yang dalam hal ini dikelompokkan kedalam empat kualifikasi, yaitu baik, cukup, agak baik, dan kurang.

Kemudian dilanjutkan dengan analisis regresi untuk mengukur pengaruh variabel independen terhadap variabel dependen. Dalam hal ini, variabel independen adalah jaringan komunikasi dan motivasi keagamaan, sedangkan variabel dependen adalah gerakan keagamaan mahasiswa. Karena itu, analisis regresi yang dilakukan adalah pengaruh variabel jaringan komunikasi dan motivasi keagamaan terhadap pemikiran keagamaan. Kemudian dilanjutkan dengan menganalisis pengaruh variabel jaringan komunikasi dan motivasi keagamaan secara bersama-sama terhadap variabel pemikiran keagamaan.

Untuk mengukur pengaruh hubungan tidak langsung dan hubungan total digunakan analisis jalur (Path Analysis) antara variabel exogenousdengan variabel endogenous. Dalam hal ini, variabel exogenous adalah jaringan komunikasi, motivasi keagamaan dan pemikiran keagamaan mahasiswa. Sedangkan varibel endogenous adalah gerakan keagamaan mahasiswa. Karena itu, analisis jalur yang dilakukan adalah pengaruh variabel jaringan

'Sevilla, CG, 1993. Pengantar Metodotogi Penelitian terjemahan Alimudin Tuwu, Jakarta: Universitas Indonesia Press.

"Burhan Bungin, 2006. Analisis Data Penelitan Kualitatif Jakarta : PT RajaGrafindo Persada, h. 131. 
komunikasi terhadap gerakan keagamaan mahasiswa melalui variabel pemikiran keagamaan dan pengaruh variabel motivasi keagamaan terhadap gerakan keagamaan mahasiswa melalui variabel pemikiran keagamaan mahasiswa. Kemudian dilanjutkan dengan analisis jalur variabel jaringan komunikasi, motivasi keagamaan dan pemikiran keagamaan secara bersama-sama terhadap gerakan keagamaan mahasiswa.

Pemikiran keagamaan dalam Islam adakalanya bersifat kontekstual atau liberal dan adakalanya bersifat tekstual atau literal. Hal ini sangat tegantung kepada sudut pandang pemahaman terhadap ajaran agama atau teks kitab suci. Pemahaman Islam tekstual memiliki kecenderungan pada demensi exteriot (luar) sehingga mengabaikan demensi kontekstual yang lebih menekankanpada subtansi danrasional. Hal semacam ini memberikan warna terhadap corak pemikiran keagamaan sehingga muncul komunitas yang mengklaim sebagai kelompok Islam liberal. Di sisi lain, ada komunitas yang mengklaim sebagai kelompok Islam fundamentalis.

Corak pemikiran Islam semacam ini memberikan pengaruh besar terhadap gerakan-gerakan keagamaan yang berkembang di masyarakat, terutama di kalangan mahasiswa. Gerakan keagamaan (Islam) dapat dibedakan menjadi dua bentuk, yakni gerakan keagamaan yang bersifat moderat dan gerakan keagamaan yang bersifat radikal. Gerakan yang bersifat moderat secara politik tidak menawarkan alternatif radikal; sedangkan gerakan radikal menawarkan alternatif yang cenderung konfrontatif terhadap lawannya.

Gerakan Islam yang muncul ke permukaan sebagai respon terhadap masalah-masalah kontemporer dengan muara pada perjuangan menegakkan syariat Islam di Indonesia. Pengaruh pemikiran keagamaan terhadap gerakan keagamaan ini dimungkinkan juga dipengaruhi oleh jaringan komunikasi dan motivasi keagamaan yang dimiliki oleh seseorang. Dalam hal ini, jaringan komunikasi dapat dikategorikan menjadi dua macam, yakni komunikasi terhadap tokoh-tokoh kharismatik secara individual dan komunikasi terhadap kelompokkelompok Islam kontemporer. Sementara motivasi keagamaan didasarkan pada lima tingkat kebutuhan, yakni fisiologis, rasa aman, cinta, harga diri dan aktualisasi diri.

Oleh karena itu, kerangka berpikir yang dibangun dalam penelitian ini dapat dirumuskan sebagai berikut:

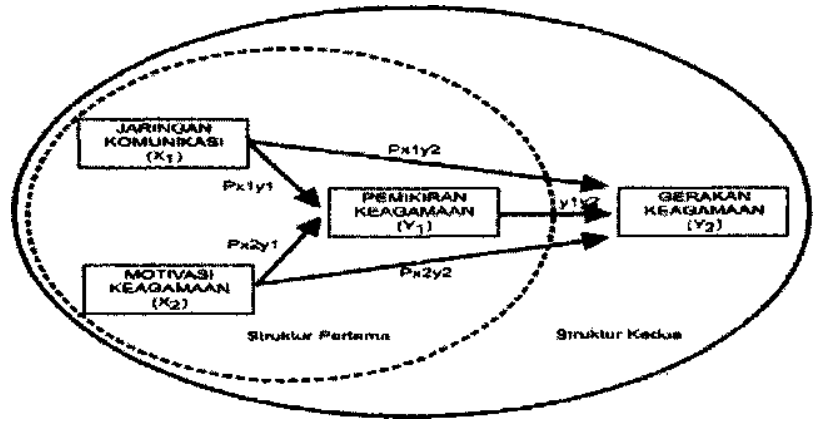

Gambar: Struktur hubungan antar variabel penelitian pengaruh jaringan komunikasi, motivasi keagamaan, dan pemikiran keagamaan terhadap gerakan keagamaan mahasiswa

Persamaan:

$$
\begin{aligned}
& \mathrm{PXjy}_{2}=\mathrm{PXjy}_{2}+\mathrm{Px}_{1} \mathrm{y}_{1} \cdot \mathrm{Py}_{1} \mathrm{y}_{2} \\
& \mathrm{Px}_{2} \mathrm{y}_{2}=\mathrm{Px}_{2} \mathrm{y}_{2}+\text { Px.yj.Pyjy, }
\end{aligned}
$$

Berdasarkan kerangka berpikir tersebut, maka hipotesis penelitian "Varian Pemikiran dan Gerakan Keagamaan" adalah sebagai berikut:

1. Jaringan komunikasi dan motivasi keagamaan secara bersama-sama berpengaruh terhadap pemikiran keagamaan.

2. Jaringan komunikasi, motivasi keagamaan, dan pemikiran keagamaan secara bersama-sama berpengaruh terhadap gerakan keagamaan.

\section{PEMBAHASAN}

Dalam penelitian ini, variabel yang dianalisis meliputi empat variabel, yakni gerakan keagamaan, pemikiran keagamaan, jaringan komunikasi dan motivasi keagaman.

\section{Gerakan keagamaan}

Berdasarkan hasil analisis deskriptif menunjukkan bahwa gerakan keagamaan mahasiswa tergolong agak radikal, sebagaimana tabel berikut:

Tabel: 01

Gerakan Keagamaan

\begin{tabular}{|l|l|r|r|r|r|}
\hline \multicolumn{2}{|c|}{ StdGeras } \\
\hline \multirow{4}{*}{ Valid } & Frequency & Percent & $\begin{array}{c}\text { Valid } \\
\text { Percent }\end{array}$ & $\begin{array}{l}\text { Cumulative } \\
\text { Percent }\end{array}$ \\
\cline { 2 - 7 } & $94-124$ = RADIKAL & 20 & 4.0 & 4.0 & 4.0 \\
\cline { 2 - 7 } & $63-93$ = AGAK RADIKAL & 272 & 54.9 & 54.9 & 59.0 \\
& $32-62$ = CUKUP MODERAT & 201 & 40.6 & 40.6 & 99.6 \\
\cline { 2 - 7 } & $<31=$ MODERAT & 2 & .4 & .4 & 100.0 \\
& Tolal & 495 & 100.0 & 100.0 & \\
\hline
\end{tabular}

Sumber: Perhitungan SPSS versi 16.0 tanggal 01 April 2012 
Tabel tersebut menunjukkan bahwa sebagian besar gerakan keagamaan mahasiswa tergolong agak radikal $(54,9 \%)$. Hal ini terlihat pada distribusi responden yang melakukan gerakan keagamaan radikal sebanyak 20 orang $(4,0 \%)$, responden yang melakukan gerakan keagamaan agak radikal sebanyak 272 orang $(54,9 \%)$. Kemudian responden yang melakukan gerakan keagamaan cukup moderat sebanyak 201 orang $(40,6 \%)$. Adapun responden yang melakukan gerakan keagamaan moderat hanya sedikit sekali, yakni sebanyak 2 orang $(0,4 \%)$.

Adanya perbedaan gerakan keagamaan tersebut dipengaruhi oleh keterlibatan mahasiswa terhadap organisasi ekstra kampus. Dalam hal ini, organisasi mahasiswa ekstra kampus yang paling besar pengaruhnya adalah KAMMI, dan karena itu KAMMI ini memiliki pengaruh yang lebih radikal terhadap gerakan keagamaan mahasiswa dibandingkan dengan organisasi lainnya, seperti : HMI, PMII, dan IMM. Hanya saja, jika dilihat dari kewilayahannya, Surakarta memiliki pengaruh yang paling besar dibandingkan wilayah lainnya, yakni Surabaya dan Yogjakarta. Hal ini dikarenakan wilayah Surakarta terdapat organinisasiorganisasi keagamaan yang bercorak eksklusif, seperti MTA, MMI, JAT, KISDI, LDII, dan sebagainya.

\section{Pemikiran Keagamaan}

Berdasarkan hasil analisis deskriptif menunjukkan bahwa pemikiran keagamaan mahasiswa tergolong cukup kontekstual, sebagaimana tabel berikut:

Tabel: 02

Pemikiran Keagamaan

\begin{tabular}{|c|c|c|c|c|c|}
\hline & \multicolumn{5}{|c|}{ StdPemirag } \\
\hline & & Frequency & Percent & $\begin{array}{c}\text { Valid } \\
\text { Percent }\end{array}$ & $\begin{array}{c}\text { Cumulative } \\
\text { Percent }\end{array}$ \\
\hline \multirow[t]{5}{*}{ Valid } & $\begin{array}{l}\text { 73-96 = } \\
\text { TEKSTUAL/LITERAL }\end{array}$ & 17 & 3.4 & 3.4 & 3.4 \\
\hline & $\begin{array}{l}\text { 49-72 = AGAK } \\
\text { TEKSTUAL/LITERAL }\end{array}$ & 202 & 40.8 & 40.8 & 44.2 \\
\hline & $\begin{array}{l}25-48=\text { CUKUP } \\
\text { KONTEKSTUAL }\end{array}$ & 269 & 54.3 & 54.3 & 98.6 \\
\hline & $\angle 24=$ KONTEKSTUAL & 7 & 1.4 & 1.4 & 100.0 \\
\hline & Total & 495 & 100.0 & 100.0 & \\
\hline
\end{tabular}

Tabel tersebut menunjukkan bahwa sebagian besar pemikiran keagamaan mahasiswa tergolong cukup kontekstual $(54,3 \%)$. Hal ini terlihat bahwa responden yang tergolong memiliki pemikiran tekstual/literal sebanyak 17 orang $(3,4 \%)$. Responden yang tergolong memiliki pemikiran keagamaan agak tekstual atau literal sebanyak 202 orang $(40,8 \%)$. Kemudian responden yang memiliki pemikiran keagamaan cukup kontekstual sebanyak 269 orang $(54,3 \%)$. Sementara responden yang tergolong memiliki pemikiran kontekstual hanya sedikit, yakni sebanyak 7 orang $(1,4 \%)$.
Adanya perbedaan pemikiran keagamaan tersebut dipengaruhi oleh keterlibatan mahasiswa terhadap organisasi mahasiswa ekstra kampus. Dalam hal ini, organisasi HMI memiliki pengaruh yang paling besar dibandingkan organisasi mahasiswa ekstra lainnya, dan karena itu HMI merupakan organisasi ekstra kampus yang memiliki pengaruh lebih besar terhadap pemikiran keagamaan yang cukup kontekstual. Hal ini sesuai dengan karakteristik perguruan tinggj yang rasional dan moderat, sebagaimana terlihat pada kajian-kajian keagamaan yang bersifat terbuka dan rasional. Jika dilihat dari kewilayahannya, maka Surakarta juga memiliki pengaruh paling besar terhadap pemikiran yang cukup kontekstual dibandingkan dengan wilayah lainnya, yakni Surabaya dan Yogjakarta.

\section{Jaringan Komunikasi}

Berdasarkan hasil analisis deskriptif menunjukkan bahwa sebagian besar jaringan komunikasi keagamaan mahasiswa berada pada golongan"kadang-kadang" dalam hal berkomunikasi terhadap tokoh-tokoh agama garis keras dan atau kelompok-kelompok keagamaan eksklusif, sebagaimana tabel berikut:

Tabel: 03

Jaringan Komunikasi

\begin{tabular}{|c|c|c|c|c|c|}
\hline & \multicolumn{5}{|c|}{ StdKomuuas } \\
\hline & & Frequency & Percent & $\begin{array}{c}\text { Valid } \\
\text { Percent }\end{array}$ & $\begin{array}{c}\text { Cumulative } \\
\text { Percent }\end{array}$ \\
\hline \multirow[t]{5}{*}{ Valid } & $31-40=$ SELALU & 31 & 6.3 & 6.3 & 6.3 \\
\hline & $21-30=$ SERING & 141 & 28.5 & 28.5 & 34.7 \\
\hline & $\begin{array}{l}11-20=\text { KADANG- } \\
\text { KADANG }\end{array}$ & 257 & 51.9 & 51.9 & 86.7 \\
\hline & $\begin{array}{l}<10=\text { TIDAK } \\
\text { PERNAH }\end{array}$ & 66 & 13.3 & 13.3 & 100.0 \\
\hline & Total & 495 & 100.0 & 100.0 & \\
\hline
\end{tabular}

Sumber: perhitungan SPSS versi 16.0 tanggal 01 April 2012

Tabel tersebut menunjukkan bahwa sebagian besar jaringan komunikasi keagamaan mahasiswa tergolong kadang-kadang terhadap tokoh-tokoh agama garis keras dan atau kelompok-kelompok keagamaan eksklusif $(51,9 \%)$. Hal ini terlihat pada jawaban responden yang tergolong hanya kadang-kadang memiliki jaringan komunikasi sebanyak 257 orang $(51,9$ $\%)$. Kemudian responden yang tergolong sering memiliki jaringan komunikasi sebanyak 141 orang $(28,5 \%)$. Responden yang tergolong selalu memiliki jaringan keagamaan hanya sebanyak 31 orang $(6,3 \%)$. Sedangkan responden yang tergolong tidak pernah memiliki jaringan komunikasi keagamaan sebanyak 66 orang $(13,3 \%)$.

Adanya perbedaan jaringan komunikasi tidak dipengaruhi oleh aspek apapun, seperti usia, jenis 
kelamin, pendidikan sebelum masuk universitas dan bahkan keterlibatan terhadap organisasi mahasiswa ekstrakampus (ormeks), seperti HMI, KAMMI, PMII, IMM, SALAFI dan sebagainya. Hal ini mengindikasikan bahwa kampus nampaknya tidak memberikan kesempatan bagi aktivis Ormeks untuk menyelenggarakan kegiatannya di kampus. Akan tetapi, simbol-simbol Ormeks nampakketika universitas mempunyai hajat besar, terutama dalam pemilihan BEM untuk mengusung calon-calonnya.

\section{Motivasi Keagamaan}

Berdasarkan hasil analisis deskriptif menunjukkan bahwa sebagian besar motivasi keagamaan mahasiswa tergolong cukup tinggi, sebagaimana tabel berikut:

Tabel: 04

Motivasi Keagamaan

\begin{tabular}{|c|c|c|c|c|c|}
\hline & \multicolumn{5}{|c|}{ StdMotivag } \\
\hline & & Frequency & Percent & $\begin{array}{c}\text { Valid } \\
\text { Percent }\end{array}$ & $\begin{array}{c}\text { Cumulative } \\
\text { Percent }\end{array}$ \\
\hline \multirow[t]{5}{*}{ Valid } & $61-80=$ TINGGI & 168 & 33,9 & 33,9 & 33.9 \\
\hline & $41-60=$ CUKUP TINGGI & 219 & 44,2 & 44,2 & 78,2 \\
\hline & $21-40=$ AGAK RENDAH & 93 & 18,8 & 18.8 & 97.0 \\
\hline & $\angle 20=$ REND AH & 15 & 3,0 & 3,0 & 100.0 \\
\hline & Total & 495 & 100.0 & 100.0 & \\
\hline
\end{tabular}

Sumber: Perhitungan SPSS versi 16.00 tanggal 01 April 2012

Tabel tersebut menunjukkan bahwa sebagian besar motivasi keagamaan mahasiswa tergolong cukup tinggi. Hal ini terlihat bahwa responden yang tergolong memiliki motivasi keagamaan cukup tinggi sebesar $44,2 \%$. Kemudian responden yang tergolong memiliki motivasi keagamaan tinggi sebesar 33,9\%. Responden yang tergolong memiliki motivasi keagamaan agak rendah sebesar $18,8 \%$. Sedangkan responden yang tergolong memiliki motivasi keagamaan rendah hanya 15 orang $(3,0 \%)$.

Adanya perbedaan motivasi keagamaan mahasiswa tersebut dipengaruhi oleh usia dan keterlibatan terhadap organisasi mahasiswa ekstra kampus. Dalam hal ini mahasiswa yang berusia muda memiliki pengaruh cukup tinggi terhadap motivasi keagamaan dibandingkan mahasiswa yang berusia dewasa dan mahasiswa usiatua. Hal ini disebabkan oleh model pembinaan keagamaan di kampus yang sangat efektif, Di UGM dan UNS, model pembinaan dilakukan dengan sistim asistensi dan dilanjutkan dengan kajiankajian rutin di masjid kampus. Sementara di UNAIR Surabaya dilakukan dengan sistim pembinaan baca tulisAlquran (PBA) melalui sistim "mentor" atau halaqah-halaqahdan kaderisasi dakwah yang bernama SABIT (yakni siang bina iman dan takwa) atau MABIT (yakni malam bina iman dan takwa).

\section{Pengaruh Jaringan Komunikasi dan Motivasi Keagamaan Terhadap Pemikiran}

\section{Keagamaan}

Pada bagian ini, variabel bebas (independent variable) meliputi dua variabel yang secara bersamasama berkorelasi dengan sebuah variabel terikat (dependent variable). Oleh karena itu, hipotesis penelitian yang hendak diuji adalah $\mathrm{H}_{\mathrm{o}}: \mathrm{p}=0$, yakni Jaringan komunikasi (jarkom) dan motivasi keagamaan (motivag) tidak berpengaruh terhadap pemikiran keagamaan. Hasil analisis pengaruh variabel jaringan komunikasi dan motivasi keagamaan terhadap pemikiran keagamaan tersebut disajikan pada tabel berikut:

Tabel : 05

Hasil Analisis Koefisien Regresi Jaringan Komunikasi dan Motivasi Keagamaan terhadap Pemikiran Keagamaan

\begin{tabular}{|c|c|c|c|c|c|c|c|c|c|}
\hline \multicolumn{10}{|c|}{ Coefficients' } \\
\hline & & \multicolumn{2}{|c|}{$\begin{array}{l}\text { Unstandardized } \\
\text { Coefficients }\end{array}$} & \multirow{2}{*}{\begin{tabular}{|l|}
$\begin{array}{l}\text { Standardized } \\
\text { Coefficients }\end{array}$ \\
Beta \\
\end{tabular}} & & \multirow[b]{2}{*}{ Sig. } & \multicolumn{3}{|l|}{ Correlations } \\
\hline \multicolumn{2}{|c|}{ Model } & B & Std. Error & & & & Zero- order & Partial & Part \\
\hline \multirow[t]{3}{*}{1} & (C costat $t)$ & 19.805 & 1.669 & & 11.868 & .000 & & & \\
\hline & KOMUNIKASI & .504 & .075 & 279 & 6.756 & .000 & .492 & .291 & .241 \\
\hline & MOTIVASI & .346 & .034 & .421 & 10.172 & .000 & .562 & .417 & \\
\hline \multicolumn{4}{|c|}{ a. Dependent Variable; PKMIKIKAN } & & & & & & \\
\hline
\end{tabular}

Sumber: perhitungan SPSS versi 16.0 tanggal 01 April 2012

Tabel tersebut menunjukkan bahwa besaran skor koefisien regresi variabel Jaringan komunikasi dan variabel motivasi keagamaan adalah signifikan karena besaran skor sig. sebesar $0,000<0,05$, yang berarti pengaruh jaringan komunikasi dan motivasi keagamaan terhadap pemikiran keagamaan signifikan. Hal ini menjelaskan adanya pengaruh kedua variabel tersebut secara bersama-sama terhadap pemikiran keagamaan mahasiswa. Hanya saja, kontribusi pengaruh variabel motivasi keagamaan (sebesar 0,417) terhadap pemikiran keagamaan lebih besar dibandingkan dengan variabel jaringan komunikasi (sebesar 0,291). Dengan kata lain, variabel motivasi keagamaan memiliki pengaruh yang lebih besar terhadap variabel pemikiran keagamaan.

Pengaruh kedua variabel tersebut terhadap pemikiran keagamaan tergolong cukup lemah karena skor Adjusted $R$ Square yang dihitung sebesar 0,371 . Hal ini berarti bahwa besaran pengaruh variabel jaringan komunikasi dan motivasi keagamaan secara bersama-sama terhadap pemikiran keagamaan yang fundamental adalah sebesar $37,1 \%$, sedangkan sisanya sebesar $62,9 \%$ dipengaruhi oleh variabel lain yang tidak termasuk dalam penelitian ini. Dengan kata lain, pemikiran 
keagamaan mahasiswa lebih banyak dipengaruhi oleh variabel lain dibandingkan dengan jaringan komunikasi dan motivasi keagamaan.

\section{Pengaruh Jaringan Komunikasi, Motivasi Keagamaandan Pemikiran Keagamaan Terhadap Gerakan Keagamaan}

Pada bagian ini, variabel yang dianalisis adalah variabel jaringan komunikasi, variabel motivasi keagamaan, variabel pemikiran keagamaan dan variabel gerakan keagamaan. Hubungan antar variabel tersebut dianalisis dengan menggunakan "analisis jalur(Path Analysis)", yakni suatu analisis hubungan kausal antar variabel dengan tujuan untuk mengetahui pengaruh langsung dan pengaruh tidak langsung serta pengaruh total. ' Dalam analisis jalur, dibedakan antara dua jenis variabel, yakni variabel yang menjadi pengaruh \{exogenous variable) dan variabel yang dipengaruhi (endogenous).

Hipotesis penelitian yang hendak diuji adalah $\mathrm{H}_{\mathrm{o}}$ : $\mathrm{p}=0$. yakni jaringan komunikasi (jarkom), motivasi keagamaan (motivag), dan pemikiran keagamaan (pemirag) tidak berpengaruh terhadap gerakan keagamaan. Hasil analisis pengaruh variabel jaringan komunikasi, motivasi keagamaan, dan pemikiran keagamaan terhadap gerakan keagamaan tersebut disajikan pada tabel berikut:

Tabel: 06

Hasil Analisis Koefisien Regresi Jaringan

Komunikasi, Motivasi Keagamaan, dan Pemikiran Keagamaan Terhadap Gerakan Keagamaan

\begin{tabular}{|c|c|c|c|c|c|c|c|c|c|}
\hline \multicolumn{10}{|c|}{ (oeff iden Is" } \\
\hline & & \multicolumn{2}{|c|}{$\begin{array}{l}\text { Unstandardi Ad } \\
\text { Coefficien Is }\end{array}$} & \multirow{2}{*}{$\begin{array}{c}\begin{array}{c}\text { Standardized } \\
\text { Coefficients }\end{array} \\
\text { Beta }\end{array}$} & & \multirow[b]{2}{*}{ Sig. } & \multicolumn{3}{|c|}{ Crelation } \\
\hline \multicolumn{2}{|c|}{ Mix el } & B & Sid. F.rror & & & & order & Partial & Pari \\
\hline \multirow[t]{4}{*}{1} & (Con slant $\mathrm{j}$ & 17.196 & 1.66 .1 & & 10.340 & .000 & & & \\
\hline & KOMUNIKASI & 097 & .069 & .045 & $\begin{array}{lll}14 & 10\end{array}$ & .159 & .480 & .063 & .037 \\
\hline & MOTIVASI & 287 & .033 & .293 & 8725 & 000 & .643 & .366 & .230 \\
\hline & PKMIKIRAN & .693 & .040 & .583 & P. 482 & .000 & .769 & .619 & 461 \\
\hline a. & pendent Variab & $\mathrm{AK}$ & & & & & & & \\
\hline
\end{tabular}

Sumber: perhitungan SPSS versi 16.0 tanggal 01 April 2012

Tabel tersebut menunjukkan bahwa koefisien regresi variabel jaringan komunikasi terhadap gerakan keagamaan mahasiswa tidak signilikan karena besaran skor sig. 0,159>0,05 yang berarti besaran skor sig. ini lebih besar dibandingkan dengan signifikansi 0, 05 atau sig. 0,000>0,05. Karena itu, dapat disimpulkan bahwa variabel jaringan komunikasi tidak berpengaruh terhadap variabel gerakan keagamaan mahasiswa. Sementara itu, koefisien regresi variabel motivasi keagamaan dan pemikiran keagamaan berpengaruh terhadap variabel gerakan keagamaan mahasiswa karena masing-masing variabel memiliki skor sig. 0,000 $<0,05$ yang berarti keduanya memiliki pengaruh yang signifikan terhadap gerakan keagamaan.

Secara parsial, pengaruh variabel jaringan komunikasi terhadap gerakan keagamaan adalah 'v'xi $\mathbf{v M}{ }^{=} 0,063$, kemudian pengaruh variabel motivasi keagamaan terhadap gerakan keagamaan adalah .2x2xivi $=0,366$, dan pengaruh variabel pemikiran keagamaan terhadap gerakan keagamaan adalah 2vixix2 0,619. Berdasarkan hasil parsial tersebut dapat diketahui bahwa variabel independent yang paling kuat pengaruhnya terhadap gerakan keagamaan adalah pemikiran keagamaan. Oleh karena itu, dapat disimpulkan bahwa motivasi keagamaan dan pemikiran keagamaan memiliki pengaruh yang cukup besar terhadap gerakan keagamaan mahasiswa. Akan tetapi, secara keseluruhan variabel exogenous yang paling kuat/besar pengaruhnya terhadap gerakan keagamaan adalah pemikiran keagamaan, yakni $r_{v_{2 v 112}}=0,619^{2}$ atau $38,31 \%$.

Pengaruh ketiga variabel tersebut terhadap gerakan keagamaan tergolong cukup kuat karena skor Adjusted $R$. Square yang dihitung sebesar 0,656. Hal ini berarti bahwa besaran pengaruh variabel jaringan komunikasi, motivasi keagamaan, dan pemikiran keagamaan secara bersama-sama terhadap gerakan keagamaan yang radikal adalah sebesar 65,6\%, sedangkan sisanya sebesar $34.49 \%$ dipengaruhi oleh variabel lain yang tidak termasuk dalam penelitian ini. Dengan kata lain, gerakan keagamaan yang radikal lebih banyak dipengaruh oleh motivasi keagamaan dan pemikiran keagamaan mahasiswa.

Oleh karena itu, dapat disimpulkan bahwa semakin kuat jaringan komunikasi dengan tokoh-tokoh garis keras dan atau kelompok keagamaan eksklusif dan semakin tinggi motivasi keagamaan dengan tuntutan harga diri dan aktualisasi diri serta semakin fundamental pemikiran keagamaan, maka semakin radikal gerakan keagamaan mahasiswa.

\section{Pembahasan Penelitian}

Sebagaimana tersebut di atas bahwa pemikiran keagamaan mahasiswa tergolong cukup kontekstual. 
Hal ini dapat dilihat pada aktivitas keagamaan mahasiswa yang berkembang di kampus, terutama yang berkaitan dengan dengan kajian-kaijan keislaman.Kajian-kajianyang demikian ini memberikan ruang kebebasan bagi semua pemeluk agama, khususnya mahasiswa untuk mengekspresikan tuntutan spiritualitasnya, yakni merubah pola-pola keberagamaan yang rigit dan eksklusif dengan menggagas dan mengembangkan paham-paham keagamaan yang interpretatif (terbuka dan inklusif). Keberagamaan yang interpretatif pada gilirannya harus mengakui doktrin agama yang bersifat partikulatif, sehingga tidak bisa menegasikan particularitas historis agama yang lain. ${ }^{10}$ Pemahaman keagamaan semacam ini termasuk pemahaman kontekstual yang dapat dilihat pada kajiankajian keislaman yang diselenggarakan oleh masyarakat kampus.

Pemikiran keagamaan mahasiswa yang kontekstual dan rasional sesuai dengan kultur perguruan tinggi yang memiliki pemikiran modern. Dr. Helmy mengatakan: "Pada prinsipnya, akal itu terbatas sehingga manusia berbeda antara satu dengan yang lain. Kalau agama dipahami secara dogmatis saja tanpa melibatkan rasio/pemikiran, maka agama akan menciptakan radikalisme"."Pemikiran keagamaan semacam ini sebenarnya telah mengarah kepada pemikiran Islam liberal, yakni suatu pemikiran yang mengandung makna adanya gagasan yang secara terus menerus dalam memberikan pemahaman atas kitab suci untuk disesuaikan dengan modernitas dan rasionalitas. ${ }^{12}$

Dalam menafsirkan teks-teks suci agama, pemikiran Islam liberal menurut Bahtiar Effendi (dalam Halid Alkaf) setidaknya melalui tiga pola, yakni: subtantif, kontekstual, dan rasional. Pada makna subtantif, kelompok Islam liberal memahami ajaran agama pada inti yang terkandung di dalamnya.Pada makna kontekstual, kelompok Islam liberal menafsirkan teks-teks keagamaan dengan mendasarkan situasi dan kondisi.Pada makna rasional, kelompok Islam liberal berusaha memaknai ajaran agama dengan nalar yang sehat dan objektif.Ketiga pola penafsiran ini dipakai dalam merespon problem keagamaan, sosial-budaya, danpolitik. ${ }^{13}$
Dalam hal ini, pemikiran Islam liberal yang dianut oleh mahasiswa adalah liberalisme Islam moderat, bukan liberalisme Islam radikal, yakni mereka yang berpandangan bahwa ketidak-adilan yang terjadi selama ini disebabkan oleh adanya struktur sosial yang timpang, baik yang dianut oleh negara ataupun oleh individu. ${ }^{14}$ Pemikiran semacam ini menjunjung tinggi nilai-nilai persamaan (equality) sehingga memunculkan paham pluralisme agama dan kesetaraan gender. Paham pluralisme agama berpandangan bahwa semua agama adalah sama benarnya dan sama validnya, sedangkan paham kesetaraan gender berpandangan bahwa perbedaan laki-laki dan perempuan itu ditentukan oleh kondisi sosial budaya, dan karena itu dimungkinkan menuntut persamaan hak antara lakilaki dan perempuan dalam soal hak sosial dan juga seksual. Artinya, kepuasan seksual dapat diperoleh dari sesama perempuan. ${ }^{15}$

Pemikiran Islam liberal radikal semacam itu mendapat kritikan yang tajam dari kalangan civitas akademika.Hal ini terlihat pada kajian-kajian mahasiswa yang bertemakan anti sekularisme, pluralisme dan liberalisme, yang dikenal dengan gerakan anti Sipilis. Biasanya, ada lembaga sosial keagamaan yang cukup intens menolak ide-ide "Sipilis", sebut saja misalnya: Majelis Ulama Indonesia (MUI), selain itu, ada beberapa kelompok keagamaan yang bersikap sama, antara lain: FPI, MMI, Hidayatullah dan organisasi yang memiliki ideologi keagamaan konservatif, bahkan NU dan Muhamadiyah. Akan tetapi, kalangan kampus juga memberikan perlawanan yang sama terhadap gencarnya gerakan "Sipilis" itu meskipun bukan berhaluan fundamentalisme, melainkan liberalisme moderat yang cenderung mendasarkan pemahaman secara subtantif dan kontekstual dalam memahami teks suci agama.

Pemikiran keagamaan yang cukup kontekstual itu nampaknya tidak sejalan atau sinergis dengan gerakan keagamaan mahasiswa yang cenderung agak radikal. Mestinya, secara hipotetis dapat dikatakan bahwa "semakin kontekstual pemikiran keagamaan mahasiswa maka semakin moderat gerakan keagamaan mahasiswa". Akan tetapi, temuan

\footnotetext{
10 Haqqul Yaqin, 2009. Agama dan kekerasan dalam Transisi Demokrasi di Indonesia, Yogjakarta: Penerbit eLSAQ Press, h. 37.

"Wawancara dengan informan tangggal 10 Maret 2012

"2harles Kurzman, 1998.Liberal Islam A Sourcebook, Oxford: Oxford University Press, USA, h. 139.

${ }^{3}$ Halid Alkaf, 2011.Quo Vadis Liberalisme Islam Indonesia, Jakarta: PT Kompas Media Nusantara, h. xxi

${ }^{4}$ Zuly Qodir, 2010.Islam Liberal: Varian-Varian Liberalisme Islam di Indonesia 1991 - 2002, Yogjakarta: Penerbit Lkis, hal. 130-131

"Zarkasyi, 200S.Libera/isasi Pemikiran Islam, Gerakan Bersama Missionaris, Orientalis, dan Kolonialis, Gontor: CIOS-ISID, h. 105.
} 
penelitian menunjukkan bahwa pemikiran keagamaan mahasiswa bersifat kontekstual tetapi gerakan keagamaan mahasiswa bersifat radikal.Hal ini mungkin terjadi karena orientasi pemikiran keagamaan dan atau pemahaman agama bagi mahasiswa bukan kepada ideologi gerakannya, tetapi lebih kepada kegiatan keislamannya.

Dengan demikian. eorak pemikiran keagamaan belum tentu berpengaruh terhadap gerakan keagamaan mahasiswa. Hal ini sangat tergantung pada konteks yang berkembang di sekitarnya, misalnya masalah tradisi atau budaya tentu akan berbeda dengan hukum atau pranata sosial lainnya. Halid Alkaf mengatakan bahwa penilaian terhadap pemikiran dan gerakan keagamaan seseorang atau lembaga tertentu tidak bisa bersifat tunggal dan homogen.Seorang bisa saja memiliki pemikiran liberal dalam masalah sosial politik, tetapi memiliki pandangan yangfundamentalis dalam masalah teologi. ${ }^{16}$ Dalam konteks pemikiran semacam ini dimungkinkan terdapat faktor lain yang mempengaruhi karakteristik pemahaman keagamaan yang berbeda-beda.

\section{PENUTUP}

Sebagai penutup dapat disimpulkan bahwa pemikiran keagamaan mahasiswa cukup bervariasi yang terwujud dalam berbagai ragam organisasi mahasiswa ekstra kampus dan kelompok keagamaan eksklusif. seperti HMI, PMII. KAMMI, IMM, dan HT1 serta SALAFI. Dari berbagai ragam pemikiran tersebut sebagian bercorak eksklusif, dan sebagian bercorak inklusif karena itu gerakan-gerakan keagamaan sebagian cenderung moderat dan sebagian cenderung radikal. Pemikiran keagamaan berpengaruh terhadap gerakan keagamaan mahasiswa. Pemikiran keagamaan mahasiswa lebih bercorak kontekstual sesuai dengan karakteristik perguruan tinggi yang rasional dan moderat. Sementara gerakan keagamaan mahasiswa cenderung lebih radikal. Hal ini mungkin terjadi karena orientasi pemikiran keagamaan mahasiswa bukan pada ideologi gerakannya, melainkan kegiatan keislamannya.

Berdasarkan temuan tersebut, maka saran/rekomendasi dapat diirumuskan sebagai berikut:

1. Hendaknya pemerintah melalui Kementerian Pendidikan Nasional dan Kementerian Agama dapat melakukan deteksi dini terhadap kemunculan paham-paham radikal di perguruan tinggi melalui optimalisasi peran rektorat untuk mengevaluasi, memfasilitasi dan mengkoordinasi kajian keislaman di kampus, baik yang dilakukan oleh organisasi mahasiswa intra maupun ekstra kampus.

2. Hendaknya Perguruan Tinggi Umum bekerja sama dengan Perguruan Tinggi Islam (IAIN, UIN) dalam pembelajaran Pendidikan Agama Islam di PTU, dengan menyusun kurikulum PAI yang diperkuat dengan aspek kebangsaan dan atau keindonesiaan.

\section{DAFTAR PUSTAKA}

Abdul Aziz dan Imam Tholkhah, ed., 1 989, Gerakan Islam Kontemporer di Indonesia, Jakarta: PT Temprint.

Bramen, Yulia, 2002, Memadu Metode Penelitian Kualitatif dan Kuantitatif Yogjakarta: Pustaka Pelajar

Burhan Bungin, 2006. Analisis Data Penelitan Kualitatif, Jakarta: PT RajaGrafindo Persada.

Charles Kurzman, 1998, Liberal Islam A Sourcebook, Oxford: Oxford University Press, USA.

Creswell, John W., 2010, Research Desairt: Pendekatan Kualitatif, Kuantitatif, Mixed, Yogakarta: Pustaka Pelajar.

Fatihul Himami, 2011, Islam Karbitan=ls1am Radikal di Indonesia, http://www. diunduh tanggal 13 Maret 2012.

Halid Alkaf, 2011, Quo Vadis L iberalisme Islam Indonesia, Jakarta: PT Kompas Media Nusantara.

Hamid Fahmv Zarkasyi, 2008, Liberalisasi Pemikiran Islam, Gerakan Bersama Missionaris, Orientalis, dan Kolonialis, Gontor: CIOS-1SID.

Haqqul Yaqin, 2009, Agama dan kekerasan dalam Transisi Demokrasi di Indonesia, Yogjakarta: Penerbit eLSAQ Press

Hartono, 2010, SPSS 16.0 Analisis Data Statistika dan Penelitian, cet III, Yogjakarta: Pustaka pelajar.

Leonard Binder, 1988, Islamic Liberalism, Chicago: Chicago University. 